\title{
Proximal Connecting Fiber
}

National Cancer Institute

\section{Source}

National Cancer Institute. Proximal Connecting Fiber. NCI Thesaurus. Code C33416.

A protein complex associated with the distal end of the centriole that is involved in

centriole localization. 